\title{
Psychosocial factors associated with adherence to treatment and quality of life in people living with HIV/AIDS in Brazil
}

\author{
Fatores psicossociais associados para adesão ao tratamento e \\ qualidade de vida de pessoas que vivem com HIV/AIDS no Brasil \\ Prisla Ücker Calvetti', Grazielly Rita Marques Giovelli², Gabriel José Chittó Gauer³, \\ João Feliz Duarte de Moraes ${ }^{4}$
}

\section{Keywords}

HIV, AIDS, adherence, social support, quality of life.

\section{Palavras-chave}

HIV, AIDS, adesão, suporte social, qualidade de vida.

\section{RESUMO}

Objetivo: $O$ objetivo deste artigo foi investigar os fatores biopsicossociais para adesão e qualidade de vida de pessoas que vivem com HIV/AIDS bem-sucedidas no tratamento de saúde. Métodos: Trata-se de estudo transversal realizado com 120 participantes portadores de HIV do sul do Brasil. Entre as variáveis estudadas, destacam-se: estresse percebido, suporte social, sintomas de ansiedade e depressão e qualidade de vida. Resultados: Os resultados apontam que a adesão ao tratamento moderada para alta com boa percepção do suporte social indica melhor qualidade de vida. Conclusão: $\mathrm{O}$ suporte social e o tratamento antirretroviral têm impacto nas condições físicas, promovendo aumento na resposta imunológica e na qualidade de vida.

1 Pontifícia Universidade Católica do Rio Grande do Sul (PUCRS). Centro Universitário La Salle (Unilasalle Canoas). 2 PUCRS.

3 University of Maryland System. PUCRS, Programa de Pós-graduação em Psicologia, Grupo de Pesquisa, Avaliação e Intervenção em Saúde Mental.

4 PUCRS, Departamento de Estatística. Universidade Federal do Rio Grande do Sul (UFRGS), Departamento de Matemática.

Correspondence address to: Prisla Ücker Calvetti

Centro Universitário La Salle (Unilasalle)

Av. Victor Barreto, 2288, Centro

90210-000 - Canoas, RS, Brazil

E-mail: prisla.calvetti@gmail.com 


\section{INTRODUCTION}

The treatment of people living with HIV/AIDS can trigger psychological reactions, such as anxiety and depression, which require them to receive special attention and, at times, psychological support. Upon finding out about possible adverse effects of medications, either from reading the medication insert or obtaining information from professionals or friends, some patients will experience more severe symptoms?.

The anxiety symptoms seen in HIV carriers are related to uncertainties regarding the evolution of the disease and clinical progress, as well as fear of pain, suffering and physical deterioration, treatment and death ${ }^{2}$. These symptoms can also be characterized as a response to stressful situations, which vary according to the interpretation of each person.

Depression is commonly associated with the presence of negative beliefs regarding the disease and feelings of hopelessness that impair the person's motivation to take care of his health and undermine confidence in his ability to cope with the demands of treatment ${ }^{17}$. Manifestations of anxiety can occur in specific ways, such as: the fear of having infected partners and/or children; the apprehension towards disclosure of the diagnosis and fear of implicit and explicit rejection; changes in the therapeutic regimen due to failure or intolerance; variations in CD4+ T cell count and in viral load; and the difficulties associated with safe sex.

Social support helps people with chronic diseases, such as HIV/AIDS, adapt to their conditions and can mitigate the impact of prejudice and discriminatory situations. It contributes to a greater adherence to treatment and an increase in quality of life. From this health-illness process perspective, many HIV carriers face an impact on their quality of life, which is understood as a person's perception of his position in life within the context of culture and system of values, in relation to his objectives, expectations, standards and preoccupations $^{3,4}$. Quality of life related to health involves concepts associated with one's own health, functional status, psychological well-being, happiness and satisfaction of needs?

However, the non-existence of a cure for most chronic diseases has revealed that measuring quality of life is indispensible to the evaluation of treatment strategies and their cost-benefit analysis. Measuring quality of life becomes an important tool to guide the allocation of resources and the implementation of health programs. It is an important factor in the knowledge of mental health professionals, in patient's adherence to treatment (medical and pharmacological) and in understanding the role of psychosocial aspects such as stress, anxiety, depression and social support, which help strengthen adherence to treatment and improve quality of life.

It is worth highlighting that, with the advent of antiretroviral drugs, there has been an increase in survival time and an improvement in the quality of life of HIV patients, lead- ing to a change in life expectancy. Due to this change in the current outlook, the psychosocial aspects involved have also changed, resulting in diminished fear of imminent death and a necessity to restructure one's life to live with the new situation. In this sense, it includes the possibility of maintaining established relationships with people from work, family and one's community, as well as the possibility of forming new relationships with new people.

For these reasons, this article investigates the psychosocial factors that influence the adherence to treatment and the quality of life of individuals living with HIV/AIDS in treatment.

\section{METHODS}

This is cross-sectional study.

\section{Participants}

This investigation had the participation of 120 adults, male and female, between the ages of 18 and 65, diagnosed as HIV/AIDS carriers. All of them had been undergoing antiretroviral treatment for at least one month and were patients of the public health services in Porto Alegre, Rio Grande do Sul. The criteria for participation included: being older than 18 years of age, undergoing antiretroviral treatment that had started at least one month before the investigation, agreeing to participate in the investigation and being younger than 65 years of age (due to the comorbidity that can exist in older patients). The criteria for exclusion included: pregnancy; the presence of mental illness that impedes comprehension; and psychotherapy.

\section{Instruments}

The study used the following instruments: questionnaires regarding sociodemographic data and clinical status - age, sex, education, relationship status, employment status, time of diagnosis, stage of HIV infection, antiretroviral therapy used, T CD4+ lymphocyte count (immune system) and viral load.

Beck Depression Inventory: comprising 21 items, with a scoring system based on variable responses of 0 to 4 (absent, light, moderate and heavy), this inventory makes it viable to quantify the intensity of the symptoms ${ }^{6}$. The Cronbach coefficient obtained was alpha 0.91 .

Beck Anxiety Inventory evaluates the intensity of clinical anxiety (self reported) using 21 scored items with a minimum value of 0 and a maximum value of 63 , the highest score corresponding to the highest level of anxiety ${ }^{7}$. The Cronbach coefficient obtained was alpha 0.92 .

Perceived Stress Scale (PSS): the PSS is based on 14 questions with response options varying on a scale from 0 to 4 to indicate stress level. Scores can vary from 0 to $56^{8}$. The Cronbach coefficient obtained was alpha 0.87 . 
Social Support Scale for People Living with HIV/AIDS: an instrument used to measure perceived social support and the patient's sense of contentment. It has been validated in Brazil ${ }^{9}$, is composed of 24 items, and is divided into two factors: emotional support and instrumental support. The Cronbach coefficient obtained was 0.96 .

The World Health Organization's Instrument for Evaluating Quality of Life (WHOQOL-HIV Bref): Brazilian version ${ }^{10}$ that evaluates the generic quality of life of people living with HIV/AIDS, (comprising) 31 items constituted by six domains: Physical, Psychological, Level of Independence, Social Relationships, Environment and Spirituality/Religiousness/ Personal Beliefs ${ }^{10,11}$. The Cronbach coefficient obtained was alpha 0.77 .

CEAT-HIV - Questionnaire for evaluating adherence to antiretroviral treatment: developed and validated for the Brazilian version ${ }^{12,13}$, it aims to identify the level of adherence to antiretroviral treatment (low/insufficient, regular or strict) of people who live with HIV/AIDS. The instrument is composed of 20 questions. The Cronbach coefficient obtained was alpha 0.85 .

\section{Procedures for collecting data}

The instruments were applied on an individual basis by the researcher himself or by a trained team member in a reserved room at a public health service location, over the period of an hour. The medical records of the participants were also accessed, in order to collect data on the biological markers for viral load and CD4+. Exam records were requested from NGO members for the purpose of verifying the biological markers. All the information was kept confidential.

When the need for urgent psychological care was identified, the participant was referred to the Therapeutic Care Service (SAT in Portuguese) of the AIDS Support and Prevention Group of Rio Grande do Sul (GAPA/RS abbrev. in Portuguese). If the participant agreed to participate in the intervention-research, he would await a phone call from the research team.

\section{Procedures for analyzing data}

The sociodemographic data, clinical status and psychological aspects of this study were submitted to variable frequency analysis. The correlation between psychological aspects and biological markers was analyzed using a Pearson correlation coefficient. The association of psychosocial factors involved in the adherence to treatment and quality of life of people living with HIV/AIDS was undertaken using a chi-squared association test and afterwards a logistic regression analysis.

Logistical multiple method regression analysis utilized Forward Stepwise (Wald). The association of categoric variables with adhesion to treatment was analysed by univaried logistical regression to include the variables in the mod- el, and the criteria of the value-p up to 0.25 was adopted for inclusion. The adjustment of the logistical regression model (capacity of discrimination) was made from the area obtained below the ROC curve. The level of significance used was $5 \%$ and the data acquired was calculated and analyzed using the Statistical Package for Social Sciences 17 (SPSS) for Windows.

\section{Ethical procedures}

The study adhered to the established norms for human research (Resolution CNS no 196/96). The anonymity and confidentiality of the information obtained from medical records and responses to research instruments were guaranteed. The study was approved by the Committee on Research Ethics of the Pontifical Catholic University of Rio Grande do Sul (CEP-PUCRS decision no 08/04228) and by the Ethics Committee of the Nossa Senhora da Conceição Hospital Group (CEP-GHC decision no 101/08). Participants identified as in need of specific treatment were referred to psychological care.

\section{RESULTS}

Participants were between 20 and 65 years old $(A=42.08$ years, $S D=8.74), 50.8 \%$ were male and $56.7 \%$ were single. Sexual orientation, when reported, was predominately heterosexual (77.5\%). The sample was composed of people living with HIV/ AIDS selected from three healthcare locations, the São Lucas Hospital Infectology Clinic (43.3\%), Conceição Hospital Group (GHC abbrev. in Portuguese) (34.2\%) and a non-governmental organization, The AIDS Support and Prevention Group of Rio Grande do Sul (GAPA/RS abbrev. in Portuguese) (22.5\%).

With regards to employment status, $57.1 \%$ of the participants were unemployed. In terms of socioeconomic status, the participants were predominately lower middle class (63.3\%). $79.2 \%$ of the complete sample reported that they did not use psychiatric medication. With regards to mode of infection, sexual transmission stood out above all others (77.5\%).

The time living with an HIV infection varied between 2 and 264 months, with an average of 97 months, equivalent to eight years of infection. The mean viral load (copies/ml) identified was 456.72 copies per milliliter, with $68.3 \%$ of the sample exhibiting an undetectable viral load.

On average, participants took four pills daily, varying from one to six pills. The most common combinations of medications were two nucleoside analog reverse-transcriptase inhibitors (NARTIs) + one non-nucleoside analog reversetranscriptase inhibitor (NNRTI) (50.8\%).

Regarding perception of one's own health, $76.6 \%$ did not consider themselves to be ill and when asked "is there something wrong with you?" 56.7\% reported saying everything 
was fine. It can be observed that of the problems described, $24.8 \%$ referred to psychological conditions (signs of anxiety, sadness, fear, low self-esteem and guilt), followed by $14.5 \%$ that reported problems related to physical health (lipodystrophy, vision problems, leg operations, abdominal issues, hepatitis, immune deficiency, HIV).

On table 1, with relation to symptoms of anxiety, $49.2 \%$ of the sample presented minimum levels, with a mean score of 14.17 , which is equivalent to a light degree. With relation to symptoms of depression, $54.2 \%$ of the participants presented a low level of depression with a mean score of 14.15 , which is equivalent to a light degree.

With relation perceived stress the raw score mean 22.14 $(S D=11.05)$. The variability of the score is from 0 to 56 ; note that the score are low-mean in relation to the stress perception in this study. In relation to social support, it was observed that the greatest average fell within factor $1(M=3.56$; $S D=$ 1.00), which represents emotional social support. Factor 2, which represents instrumental support, obtained a mean of $3.41(S D=0.99)$.

In relation to the grade of adherence, participants presented a greater percentage of strict adherence (48.3\%), followed by regular adherence (47.5\%) and lastly low/insufficient adherence (4.2\%). One can observe strict and regular account for most of the percentage, totaling $95.8 \%$, pointing to an adherent sample in this study.

In the assessment of quality of life, one can observe the highest average in domain III, level of independence ( $M=$ 14.53 ; SD $=2.7$ ), which relates to mobility, daily activity, dependence on medication or treatment and work ability. This is followed by domain $\mathrm{IV}$, social relations ( $\mathrm{M}=14.35$; SD = 3.5), which refers to personal relationships, social support, sexual activity and social inclusion. Next is domain $\mathrm{V}$, environment $(M=14.04 S D=2.66)$, which includes physical security, housing, finances, care (access to quality health care and social assistance), information (acquisition of new information and new skills), leisure time, physical environment (pollution/noise/traffic/climate) and transportation. The sample featured a global mean of $14.65(\mathrm{SD}=3.67)$.

On table 2 we can observe an inverse correlation between anxiety and adherence $(r=-0.407 ; p<0.001)$, as well as a negative correlation between depression and adherence $(r=$ $-0.523 ; p<0.001)$. The total score of perceived stress showed an inverse correlation with adherence to treatment $(r=-0.416$, $p<0.001)$. Emotional social support - factor $1(r=0.441 ; p<$ $0.001)$ and instrumental social support - factor $2(r=0.339 ; p$ $<0,001)$ show highly significant correlations with adherence.

Domain II - psychological $(r=0.422 ; p<0.001)$, domain III - level of independence $(r=0.403 ; p<0.001)$, domain IV - social relationships ( $r=0.492, p<0.001)$, and domain $\mathrm{V}$ - environment $(r=0.529 ; p<0.001)$ showed a highly significant correlation with adherence. What stands out the most is domain $\mathrm{V}$ - environment, since this data can be related to the population in this study having good adaptation to living conditions and access to healthcare and to information.

Domain VI - spirituality/religion/personal beliefs $(r=$ -0.250; $p<0.001$ ) showed a significant indirect correlation with adherence. Religion and spiritual beliefs did not prove to be a resource that contributed to adherence to treatment of the HIV/AIDS carriers in this study. Only domain I - physical did not present a correlation with adherence.

Table 1. Presentation of means and standard deviations of anxiety symptoms, depression symptoms, perceived stress, social support, quality of life and adherence to treatment observed in people who have HIV/AIDS ( $N=120)$

\begin{tabular}{|c|c|c|c|c|}
\hline Variables & $\%$ & $f$ & Mean & $\begin{array}{l}\text { Standard } \\
\text { deviation }\end{array}$ \\
\hline \multicolumn{5}{|l|}{ Anxiety levels (BAI) } \\
\hline Minimum & 49.2 & 59 & & \\
\hline Light & 26.7 & 32 & & \\
\hline Moderate & 12.5 & 15 & & \\
\hline Severe & 11.7 & 14 & & \\
\hline Total score & & & 14.17 & 12.59 \\
\hline \multicolumn{5}{|l|}{ Depression levels (BDI) } \\
\hline Minimum & 54.2 & 65 & & \\
\hline Light & 15.0 & 18 & & \\
\hline Moderate & 23.3 & 28 & & \\
\hline Severe & 7.5 & 9 & & \\
\hline Total score & & & 14.15 & 12.59 \\
\hline \multicolumn{5}{|l|}{ Perceived stress (PSS) } \\
\hline Raw score & & & 22.14 & 11.05 \\
\hline \multicolumn{5}{|l|}{ Social support } \\
\hline Emotional - Factor 1 & & & 3.56 & 1.00 \\
\hline Instrumental - Factor 2 & & & 3.41 & 0.99 \\
\hline \multicolumn{5}{|l|}{$\begin{array}{l}\text { Degree of adherence to } \\
\text { treatment (CEAT-VIH) }\end{array}$} \\
\hline Low/Insufficient & 4.2 & 5 & & \\
\hline Regular & 47.5 & 57 & & \\
\hline Strict & 48.3 & 58 & & \\
\hline Total score & & & 75.78 & 10.28 \\
\hline \multicolumn{5}{|l|}{$\begin{array}{l}\text { Quality of life (WHOQOL- } \\
\text { HIV BREF) }\end{array}$} \\
\hline Domain 1 - Physical & & & 11.61 & 2.00 \\
\hline Domain 2 - Psychological & & & 13.50 & 2.40 \\
\hline $\begin{array}{l}\text { Domain } 3 \text { - Level of } \\
\text { independence }\end{array}$ & & & 14.53 & 2.7 \\
\hline $\begin{array}{l}\text { Domain } 4 \text { - Social } \\
\text { relations }\end{array}$ & & & 14.35 & 3.5 \\
\hline Domain 5 - Environment & & & 14.04 & 2.66 \\
\hline $\begin{array}{l}\text { Domain } 6 \text { - Spirituality/ } \\
\text { religion/personal beliefs }\end{array}$ & & & 10.33 & 3.04 \\
\hline Global quality of life & & & 14.65 & 3.67 \\
\hline
\end{tabular}


Table 2. Correlation between anxiety symptoms, depression symptoms, perceived stress, social support, quality of life and adherence to treatment in people living with HIV/AIDS ( $N=120)$

\begin{tabular}{lcc}
\hline & \multicolumn{2}{c}{ CEAT VIH Total score } \\
\cline { 2 - 3 } Variables & $\mathbf{r}$ & $\mathbf{p}$ \\
\hline Anxiety levels (BAI) & & \\
$\quad$ Total score & -0.407 & $<0.001$ \\
Depression levels (BDI) & & \\
$\quad$ Total score & -0.523 & $<0.001$ \\
Perceived stress (PSS) & & \\
$\quad$ Total score & -0.416 & $<0.001$ \\
Social support & & \\
Emotional - Factor 1 & 0.441 & $<0.001$ \\
Instrumental - Factor 2 & 0.339 & $<0.001$ \\
Quality of life (WH0Q0L-HIV BREF) & & \\
Domain 1 - Physical & & \\
Domain 2 - Psychological & .134 & 0.140 \\
Domain 3 - Level of independence & 0.422 & $<0.001$ \\
Domain 4 - Social relations & 0.403 & $<0.001$ \\
Domain 5 - Environment & 0.492 & $<0.001$ \\
Domain 6 - Spirituality/religion/personal beliefs & 0.529 & $<0.001$ \\
Global quality of life & -0.250 & 0.006 \\
\hline
\end{tabular}

Pearson's correlation.

The study investigated the association between sociodemographic variables, clinical status and adherence to treatment (low/insufficient, or regular or strict) in people living with HIV/AIDS and successfully receiving treatment (see Table 3). In relation to the sociodemographic variables, the two groups did not differ in regards to sex, employment status, marital status or sexual orientation. The results point to an association between social class and adherence $(p<0.001)$. The perception of being in middle class favors a climb in adherence from regular to strict. A limit association between education level and adherence was also observed $(p=0.054)$.

In the investigation regarding clinical status, the two groups did not differ in the relation between HIV transmission and use of psychiatric medication. The results highlighted a relationship between perceived health and adherence $(p=$ 0.022) and between the stage of HIV infection and adherence $(p=0.003)$. The perception of being in good health and the asymptomatic stage favored adherence to treatment.

In table 4, we can see that the variables that stand out in maintaining adherence to treatment are: depression levels $(O R=0.930 ; p<0.001)$, perceived stress $(O R=0.936 ; p$ $=0.001)$, emotional social support $(O R=1.969 ; p=0.001)$, instrumental social support $(O R=1.749 ; p=0.006)$ and overall quality of life $(O R=1.238 ; p=0.001)$. Regarding quality of life, the most noteworthy predictors of healthcare treatment belonged to domains I - physical, which refers to pain and discomfort, energy and fatigue, sleep and rest $(O R=1.272 ; p$ $=0.015) ; \|$ - psychological $(\mathrm{OR}=1.358 ; \mathrm{p}=0.001) ;$ III - level of independence $(O R=1.260 ; p=0.003) ; \mathrm{IV}$ - social relationships $(O R=1.228 ; p=0.001)$; and $V$ - environment $(O R=$ $1.465 ; p=0.001)$.
Table 3. Test of $X^{2}$ for association between sociodemographic variables, clinical status, low/insufficient or regular adherence to treatment and strict adherence in people living with HIV/AIDS ( $N=120)$

\begin{tabular}{lcccc}
\hline Variables & $\begin{array}{c}\text { Low and regular } \\
\text { adherence (f) }\end{array}$ & Strict adherence (f) & $\begin{array}{c}\text { Total } \\
(\mathbf{n}=120)\end{array}$ & $\mathbf{p}$ \\
\hline Gender & & 31 & 61 & 0.579 \\
$\quad$ Male & 30 & 27 & 59 & \\
$\quad$ Female & 32 & & & \\
Level of education & & 21 & 54 & \\
$\quad$ Elementary school & 33 & 26 & 51 & 0.054 \\
$\quad$ High school & 25 & 11 & 15 & \\
$\quad$ College & 4 & & & \\
Employment status & & 27 & 51 & 0.427 \\
$\quad$ Employed & 24 & 31 & 68 & \\
Unemployed & 37 & & & \\
Perceived health & & 2 & 11 & \\
$\quad$ Very bad orbad & 9 & 8 & 23 & 0.022 \\
$\quad$ Neither bad nor good & 15 & 48 & 86 & \\
$\quad$ Good or very good & 38 & & & \\
Social class & & 7 & 33 & $<0.001$ \\
$\quad$ Low & 26 & 51 & 87 & \\
$\quad$ Middle & 36 & & & \\
Perceived HIV stage & & 29 & 44 & 0.003 \\
$\quad$ Asymptomatic & 15 & & 76 & \\
$\quad$ Symptomatic/AlDS & 47 & & & \\
\hline
\end{tabular}

Table 4. Univariate logistic regression by the "enter" method of the variable adherence to antiretroviral therapy as a function of the numeric variables (depression levels, anxiety levels, perceived stress, social support and quality of life) in people living with HIV/ AIDS $(N=120)$

\begin{tabular}{|c|c|c|c|}
\hline Variables & OR & $\mathrm{Cl} 95 \%$ & p \\
\hline Age & 1.021 & $0.980-1.064$ & 0.324 \\
\hline \multicolumn{4}{|l|}{ Anxiety levels (BAI) } \\
\hline Total score & 0.962 & $0.932-0.994$ & 0.018 \\
\hline \multicolumn{4}{|l|}{ Depression levels (BDI) } \\
\hline Total score & 0.930 & $0.897-0.965$ & $<0.001$ \\
\hline \multicolumn{4}{|l|}{ Perceived stress (PSS) } \\
\hline Total score & 0.936 & $0.901-0.973$ & 0.001 \\
\hline \multicolumn{4}{|l|}{ Social support } \\
\hline Emotional - Factor 1 & 1.969 & $1.312-2.953$ & 0.001 \\
\hline Instrumental - Factor 2 & 1.749 & $1.176-2.602$ & 0.006 \\
\hline \multicolumn{4}{|l|}{ Quality of life (WHOQOL-HIV bref) } \\
\hline Domain 1 - Physical & 1.272 & $1.048-1.543$ & 0.015 \\
\hline Domain 2 - Psychological & 1.358 & $1.136-1.623$ & 0.001 \\
\hline Domain 3 - Level of independence & 1.260 & $1.084-1.464$ & 0.003 \\
\hline Domain 4 - Social relations & 1.228 & $1.090-1.385$ & 0.001 \\
\hline Domain 5 - Environment & 1.465 & $1.217-1.763$ & 0.001 \\
\hline $\begin{array}{l}\text { Domain } 6 \text { - Spirituality/religion/ } \\
\text { personal beliefs }\end{array}$ & 0.938 & $0.832-1.058$ & 0.299 \\
\hline Global quality of life & 1.238 & $1.098-1.395$ & 0.001 \\
\hline
\end{tabular}

OR: odds ratio.

In table 5, the analysis carried out by the stepwise method identified that the independent predictors for adherence to treatment are: social class, perceived stage of HIV infection, domain I - physical and domain $\mathrm{V}$ - environment, which refers to physical security, financial resources, social services, healthcare, opportunities for access to new information, 
leisure time, physical environment and transportation, all of which contribute to quality of life. The success rate of the logistic regression model developed was $77.4 \%$, having correctly classified 86 of 120 participants from the sample in relation to their adherence to treatment.

Table 5. Multivariate logistic regression by the "Forward Stepwise (Wald)" method of the variable adherence to antiretroviral therapy, step 4, independents variables, in people living with HIV/AIDS $(\mathrm{N}=120)$

\begin{tabular}{lccc}
\hline Variables & OR & C1 95\% & $\mathbf{p}$ \\
\hline Social class (1 = middle) & 3.5250 & $1.229-10.080$ & 0.019 \\
Perceived HIV stage (1 = symptomatic) & 0.346 & $0.138-0.871$ & 0.024 \\
Quality of life (WH0Q0L-HIV bref) & & & \\
$\quad$ Domain 1 - Physical & 1.276 & $1.010-1.613$ & 0.041 \\
$\quad$ Domain 5 - Environment & 1.415 & $1.158-1.728$ & 0.001 \\
\hline OR: odds ratio. & & &
\end{tabular}

The area $0.815>0.80$ (see ROC Curve), considered the discrimination of the logistical model as being excellent, or rather, the four independent variables which were obtained in the Stepwise model explained adhesion or not to treatment well.

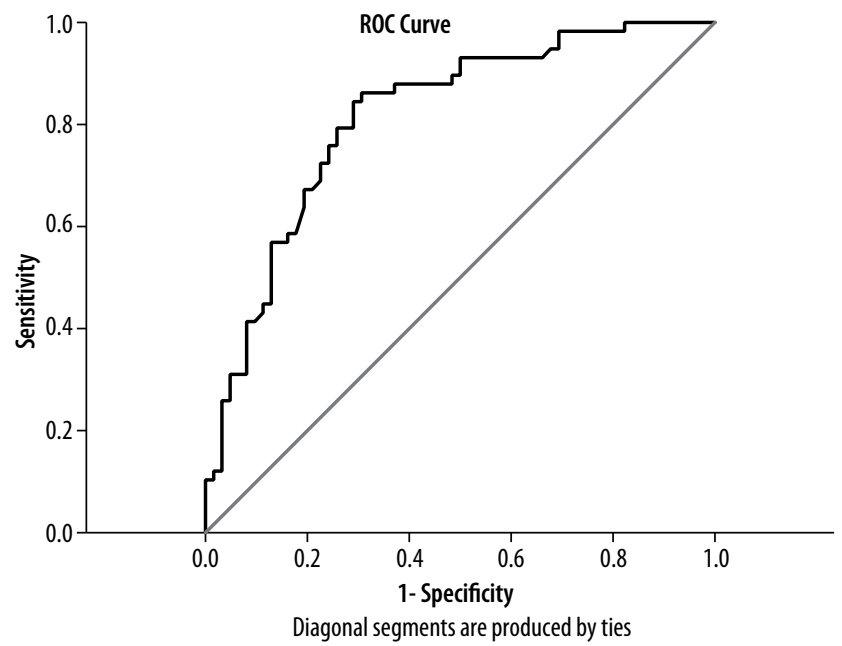

Figure 1. ROC Curve.

\section{DISCUSSION}

From this study one can infer that the participants with high scores in emotional social support present higher rates of adherence to treatment and quality of life. Studies point to the relevance of social support to confronting the disease as a factor in maintaining adherence to treatment and improving quality of $\mathrm{life}^{13}$, as well as an association between availability and satisfaction with social support, psychological well-being, adherence to treatment and positive perception of one's quality of life ${ }^{14,15}$.

Anxiety and depression symptoms can contribute to non-adherence to antiretroviral therapy which, consequent- ly, lowers immunity and increases virological response $\mathrm{e}^{16}$ and the progress of AIDS, and deteriorates quality of $\mathrm{life}^{17}$. In one previous study ${ }^{18}$, it was highlighted that people with depression, anxiety or generalized panic responses were approximately twice as non-adherent than those without a psychological disorder. Other studies ${ }^{19,20}$ report that symptoms of depression have an inverse relationship with social support in people who live with HIV/AIDS.

Worries and fear of adverse consequences can negatively influence the adherence to treatment. In addition to gastrointestinal problems such as nausea, vomiting, diarrhea, gas and acid reflux that frequently occur at the beginning or change in pharmaceutical treatment, anatomical and metabolic alterations can manifest as a result of lipodystrophy ${ }^{19}$.

The results show a significant correlation between domain II - psychological and adherence to treatment but no relationship between domain I - physical and adherence. Note that the majority of the participants regarded their perceived health to be good.

The perception of social interactions with other individuals can increase self respect, self esteem and self confidence in people living with HIV/AIDS, reducing the perception of stigmatization ${ }^{3}$. Support systems are part of a wider scope of people's lives, encompassing relationships established with schools, work, religious centers and health institutions. A previous study ${ }^{21}$ corroborates the results obtained in this study that identify living conditions and social support as variables predictive of adherence to treatment.

Satisfaction with emotional social support predicts a better perception of quality of life ${ }^{22}$. Corroborating the results obtained in the present study, other studies ${ }^{23}$ show that social support can be a factor in reducing the negative impact of being HIV positive on the lives of patients. A network of social support can be a useful strategy for adherence to treatment and improving quality of life. Other studies ${ }^{12,15,17}$ point to a significant correlation between social support and adherence to antiretroviral treatment.

Symptomatic patients with AIDS who present signs or symptoms of the disease presented a larger number of significant correlations between quality of life (physical domain; social relationships; spirituality, religion and personal beliefs) and religious well-being in comparison to the asymptomatic group ${ }^{13}$. In the current study, there was no significant correlation between domain $\mathrm{VI}$ - spirituality, religion and personal beliefs and adherence to treatment. Note that the greater percentage of participants perceive themselves to be in good health and do not present signs or symptoms of the disease. It could be that domain $\mathrm{VI}$ presents as more salient in the population with perception of regular or poor health and with signs and symptoms of the disease.

The capacity for autonomy, social support, access to healthcare and information are more prominent in the po- 
pulation of this study in relation to the perception of quality of life. Social support strengthens adherence to treatment and quality of life, and is a security factor that attenuates the impact of the disease and of the treatment.

One can observe in this investigation that the predictive factors for maintaining adherence to treatment are social class, perceived stage of HIV infection, domain I - physical, domain $\mathrm{V}$ - environment and quality of life. With regards to social class, the middle class presents itself as the reference point for adherence, as does the asymptomatic stage of the disease. In relation to quality of life, people in antiretroviral treatment that feel physically well and show no manifestations of collateral effects, fatigue or sleepiness are more adherent. It's worth noting that HIV carriers who feel good about their financial situation and secure in relation to the organization of their lives, who have good living conditions and access to healthcare and information (education) tend to better adhere to treatment.

We point out the importance of understanding the biopsychosocial aspects implicated in adherence to treatment in improving the quality of life of people who live with HIV/ AIDS. However, it's known that antiretrovirals can cause collateral effects in the short term (nausea, vomiting) and in the long term (lipodystrophy, dyslipidemia), which have an impact on quality of life ${ }^{24}$.

A study on the psychosocial impact of lipodystrophy has shown deficiencies in self-image and difficulties in social and sexual relationships ${ }^{23}$. The study identified attitudes characterized by avoidance due to shame related to a new body image, as well as sexual difficulties due to a perception of being sexually unattractive. Other researchers ${ }^{25}$ point out that the stigma surrounding the disease can cause people to develop signs and symptoms of depression that weaken the immune system and therefore the effectiveness of treatment.

It was ascertained that satisfaction with social support is associated with adherence to treatment. The importance of social support was made evident by its influence on the availability of encouragement, positive reinforcement and motivation for self-care, as well as attenuation of stimuli that negatively interfere with adherence to treatment ${ }^{14}$. Social support and psychological well-being were related to adherence to the antiretroviral treatment.

Because of the prejudice and discrimination situations still observed toward HIV positive persons, people with HIV/ AIDS may experience isolation and restrict their social relationships, exerting a negative impact on the maintenance and organization of their support networks. Patients without support or with insufficient support from family members, friends and/or significant affective relationships tend to exhibit more difficulties with adherence to treatment ${ }^{16}$.

Medical and psychosocial evaluations of patients make it possible to identify the modes by which they confront the ill- ness and the difficulties in accepting and living with the diagnosis. Healthcare teams should take these aspects into consideration when preparing treatment plans. Psychological care (individual or group therapy) should be made available to patients depending on their evaluations. Other activities, such as participation in support groups or in non-governmental organizations, may also be valid and useful for the patient to learn various forms of dealing with being HIV positive, through sharing experiences with other participants ${ }^{24}$.

\section{CONCLUSION}

The results of the current study reveal a correlation between social support, quality of life and adherence to treatment. Psychological aspects, such as anxiety, depression and perceived stress, are shown to have an inverse correlation with health improvement of patients living with HIV/AIDS. It can be inferred that the social network is a health protection factor with regards to treatment and quality of life in this population.

Social support plays an essential role in moderating stress related to the health-illness process, involving issues such as fear of death, abandonment by family and friends, job loss and social responses to being HIV positive. The results reflect the need develop strategies to strengthen social support as a factor in promoting adherence to treatment and quality of life. Furthermore, they call for investments in training psychologists and other healthcare team members to offer counseling on prevention and on the treatment of people living with HIV/AIDS.

The study brings to the attention of healthcare professionals the following predictive biopsychosocial factors in adherence to treatment by patients with HIV/AIDS: social class, stage of HIV infection, domain I - physical and domain $V$ - environment, and quality of life. The results reveal that the people in the sample present regular to strict adherence to treatment, feel good about their physical health and have access to healthcare and information about the disease. All are aspects that reinforce adherence to treatment.

We find that the psychological and social needs of those living with HIV/AIDS have changed as new antiretroviral therapies are developed, which suggests improvement in quality of life and feelings of hope. Identifying the factors that facilitate adherence to treatment by HIV/AIDS patients makes it more feasible to plan and develop new psychological interventions that are adequate to the needs of those who live with the disease.

\section{INDIVIDUAL CONTRIBUTIONS}

Prisla Ücker Calvetti - Contributed to conception and design and to drafting the article or revising it critically for 
important intellectual content or analysis and interpretation of data.

Grazielly Rita Marques Giovelli - Contributed to conception and design and to drafting the article or revising it critically for important intellectual content or analysis and interpretation of data.

Gabriel José Chittó Gauer - Contributed to the final approval of the version to be published.

João Feliz Duarte de Moraes - Contributed to analysis and interpretation of data.

\section{CONFLICTS OF INTEREST}

All authors declare they have no conflicts of interest to disclose.

\section{REFERENCES}

1. Calvetti Pü, Müller MC, Nunes MLT. Qualidade de vida e bem-estar espiritual em pessoas que vivem com HIV/AIDS. Psicol Estud. 2008;13(3):523-30.

2. Seidl EMF, Machado ACA. Bem-estar psicológico, enfrentamento e lipodistrofia em pessoas vivendo com HIV/AIDS. Psicol Estud. 2008;13(2):239-47.

3. Murphy P, Cocohoba J, Tang A, Pietrandoni G, Guglielmo J. Impact of HIV-specialized pharmacies on adherence and persistence with antiretroviral therapy. Aids Patient Care STDS. 2012;26(9):526-31

4. Seidl EMF, Melchíades A, Farias V, Brito A. Pessoas vivendo com HIV/AIDS: variáveis associadas à adesão ao tratamento antirretroviral. Cad Saúde Pública. 2007;23(10):2305-16.

5. Carrobles JA, Remor EA, Rodríguez-Alzamora L. Afontamiento, apoyo social percebido y distrés emocional em pacientes com infección por VIH. Psicothema. 2003;15(3):420-6.

6. Beck AT, Steer RA. Beck Depression Inventory Manual. San Antonio: Psychology Corporation; 1993.

7. Beck AT, Epstein N, Brown Steer RA. An inventory for measuring clinical anxiety: psychometric properties. J Consultin Clin Psychol. 1988;56(6):893-7.

8. Luft CDB, Sanches SO, Mazo GZ, Andrade A. Versão brasileira da Escala de Estresse Percebido: tradução e validação para idosos. Rev Saude Publica. 2007;41(4):606-15.

9. Seidl EMF, Tróccoli BT. Desenvolvimento de escala para avaliação do suporte social em HIV/ AIDS. Psicol Teor Pesqui. 2006;22(3):317-26.
10. WHOQOL Group. Initial steps to development the World Health Organization's Quality of life instrument (WHOQOL) module for international assessment in HIV/AIDS. AIDS Care. 200315(3):347-57.

11. Zimpel R. Avaliação da qualidade de vida de pacientes com HIV/Aids. [dissertação]. Faculdade de Medicina, Universidade Federal do Rio Grande do Sul (UFRGS), Porto Alegre, RS; 2003.

12. Remor EA, Milner-Moskovics J, Preussler G. Adaptação brasileira do Cuestionario para la Evaluación de la Adhesión al Tratamiento Antiretroviral. Rev Saude Publica. 2007:41(5):685-94.

13. Remor EA. Systematic review of the psychometric properties of the questionnaire to evaluate the adherence. Springer; 2013.

14. Nel A, Kagee A. Common mental health problems and antiretroviral therapy adherence. Aids Care. 2011;23(11):1360-5.

15. Seidl EMF, Zannon CMLC, Tróccoli BT. Pessoas vivendo com HIV/AIDS: enfrentamento, suporte social e qualidade de vida. Psicol Reflex Crit. 2005;18(2):188-95.

16. Carvalho FT, Morais NA, Koller SH, Piccinini CA. Fatores de proteção relacionados à promoção de resiliência em pessoas que vivem com HIV/Aids. Cad Saude Publica. 2007;23:2023-33.

17. Weaver EK, Llabre MM, Durán RE, Antoni MH, Ironson G, Penedo FJ, et al. A stress and coping model of medication adherence and viral load in HIV-positive men and women on highly active antiretroviral therapy (HAART). Health Psychol. 2005;24(4):385-92.

18. Campos LN, Guimarães MDC, Remien RH. Anxiety and depression symptoms as risk factors for non-adherence to antiretroviral therapy in Brazil. AIDS Behav. 2008;18(6):529-36.

19. Fernandes APM, Sanches RS, Mill J, Lucy D, Palha PF, Dalri MCB. Síndrome da lipodistrofia associada com a terapia antirretroviral em portadores do HIV: considerações para os aspectos psicossociais. Rev Latino-am Enfermagem. 2007;15(5):1041-5.

20. Vanable PA, Carey MP, Blair DC, Littlewood RA. Impact of HIV-related stigma on health behaviors and psychological adjustment among HIV-positive men and women. AIDS Behav. 2006;10(5):473-82

21. Castro EK, Remor EA. Aspectos psicossociais e HIV/Aids: um estudo bibliométrico (19922002) comparativo dos artigos publicados entre Brasil e Espanha. Psicol Reflex Crit. 2004;17(2):243-50.

22. Remor EA, Milner-Moskovics J, Preussler G. Adaptação brasileira do Cuestionario para la Evaluación de la Adhesión al Tratamiento Antiretroviral. Rev Saúde Pública. 2007:41(5):685-94

23. Holstad MK, Pace JC, de AK, Ura DR. Factors associated with adherence to antiretroviral therapy. J Assoc Nurses AIDS Care. 2006;17(2):4-15.

24. Mello VA, Malbergier A. Depression in women infected with HIV. Rev Bras Psiquiatr. 2006;28(1):10-7.

25. Brasil. Boletim epidemiológico AIDS e DST. Ministério da Saúde. Brasília, DF; 2010 